\title{
PENGARUH TINGKAT PENGUNGKAPAN CORPORATE SOCLAL RESPONSIBILITY (CSR DISCLOSURE) TERHADAP RETURN SAHAM
}

(Studi Pada PT Telekomunikasi Indonesia, Tbk)

Oleh :

Karli Soedijatno

(Dosen Program Studi Akuntansi Fakultas Pendidikan Ekonomi \& Bisnis UPI BHMN Bandung)

Asep Ismail Siddik

(Alumni Program Studi Akuntansi Fakultas Pendidikan Ekonomi \& Bisnis UPI BHMN Bandung)

\begin{abstract}
Abstrak
Kinerja manajemen perusahaan memiliki dampak terhadap pergerakan harga saham, yang dijadikan dasar oleh para investor dalam melakukan investasi. Seiring munculnya paradigma baru yang mengharuskan perusahaan melaporkan kinerja perusahaan dalam lingkungan sosialnya, yaitu Corporate Sosial Responsibility, maka menarik untuk dicermati sejauh mana investor memperhatikan informasi tersebut dalam kegiatan investasinya. Dimana reaksi investor ini akan berdampak pada pergerakan harga saham yang kemudian akan menimbulkan abnormal return. Sesuai dengan hal ini maka tujuan penelitian adalah untuk memperoleh bukti empiris mengenai pengaruh pengungkapan Corporate Sosial Responsibility terhadap terhadap return saham. Corporate Sosial Responsibility sebagai variabel bebas yang indikatornya terdiri dari tiga standard disclosure yaitu Profile Disclosure, Management Approach Disclosure, dan Performance Indicators \& Sector Supplement Performance Indicators. Return saham sebagai variabel terikat yang Average Abnormal Return sebagai indikatornya. Guna mencapai tujuan tersebut digunakan metode event study yaitu merupakan studi untuk menilai ada atau tidaknya kandungan informasi dalam suatu kejadian. Penelitian ini dilakukan pada PT Telekomunikasi Indonesia dengan melihat laporan tahunan periode 1999-2008. Berdasarkan hal tersebut, terdapat 10 laporan tahunan yang menjadi objek penelitian. Analisis data menggunakan model regresi logistik. Hasil penelitian ini bahwa tingkat pengungkapan Corporate Social Responsibility yang dijelaskan oleh tiga standard disclosures yaitu Profile Disclosure, Management Approach Disclosure, dan Performance Indicators \& Sector Supplement Performance Indicators tidak berpengaruh secara signifikan terhadap nilai Average Abnormal Return. Hal ini dimungkinkan karena masih rendahnya kesadaran investor terhadap informasi sosial yang diungkapkan perusahaan dalam laporan tahunannya, sehingga belum menjadi bahan pertimbangan investor dalam melakukan keputusan investasinya.
\end{abstract}

Kata Kunci : Corporate Sosial Responsibility, Average Abnormal Return, Profile Disclosure, Management Approach Disclosure, dan Performance Indicators \& Sector Supplement Performance Indicators 


\section{Latar Belakang Penelitian}

Kesadaran tentang pentingnya mempraktikan Corporate Social Responsibility (CSR) ini menjadi trend global seiring dengan semakin maraknya kepedulian mengutamakan stakeholders. Kemajuan teknologi informasi dan keterbukaan pasar, perusahaan harus secara serius dan terbuka memperhatikan Corporate Social Responsibility. Kehilangan rekan bisnis maupun risiko terhadap citra perusahaan (brand risk) tentu akan memberi dampak pada kelangsungan hidup usaha yang telah berjalan.

Survey global yang dilakukan oleh The Economist Intelligence Unit menunjukkan bahwa $85 \%$ eksekutif senior dan investor dari berbagai organisasi menjadikan CSR sebagai pertimbangan utama dalam pengambilan keputusan (Warta Ekonomi yang dikutip oleh Yosefa Sayekti dan Ludovicus Sensi Wondabio (2007:2)). Berbagai penelitian sebelumnya menunjukkan bahwa jumlah perusahaan yang melakukan pengungkapan CSR dalam laporan tahunannya semakin bertambah. Demikian juga dengan jumlah dan jenis informasi CSR yang diungkapkan semakin meningkat. Banyak perusahaan semakin menyadari pentingnya menerapkan program CSR sebagai bagian dari strategi bisnisnya.

Salah satu perusahaan yang sangat memperhatikan tentang masalah tanggungjawab sosial perusahaan adalah PT Telekomunikasi Indonesia,Tbk. (Telkom). Hal ini dapat dilihat dengan penerbitan laporan keberlanjutan (sustainability report), yang merupakan suatu jenis laporan tentang apa saja yang telah dilakukan perusahaan khususnya dalam hubungan perusahaan dengan lingkungan sosial dan pada umumnya mengenai kinerja perusahaan secara keseluruhan selama satu periode. Dalam pelaporan sustainability report ini berbeda dengan laporan tahunan perusahaan pada umumnya, karena dalam sustainability report mendorong perusahaan untuk melaporkan kegiatan sosial perusahaan secara lengkap. Dan hal ini secara tidak langsung akan mendorong juga kepedulian perusahaan terhadap dunia sosial. Sustainability report dikeluarkan Telkom untuk melaporkan kegiatan perusahaan yang berkaitan langsung dengan keberlanjutan usaha maupun kegiatan tanggung jawab sosial, atau Corporate Social Responsibility, yang memiliki manfaat yang berkelanjutan bagi mereka yang dituju. Penyusunan Sustainability report mengacu pada GRI yang merupakan pedoman untuk menyusun sustainability report sehingga perusahaan dapat melaporkan kegiatan dan informasi pertanggung jawaban sosial yang dilakukan perusahaan dengan lebih optimal. Dalam GRI ini terdapat tiga standard disclosure untuk menjelaskan tingkat pengungkapan CSR dari perusahaan, tiga standard disclosure tersebut adalah Profile Disclosure, Management Approach Disclosure, Performance Indicators \& Sector Supplement Performance Indicators.

Menurut Rina Tresnawati (2008:2), CSR merupakan suatu konsep integrasi yang menggabungkan aspek bisnis dan sosial dengan selaras agar perusahaan dapat membantu tercapainya kesejahtraan stakeholders, serta dapat mencapai profit maksimum sehingga dapat meningkatkan harga saham. 
Berikut adalah rata-rata harga saham perusahaan 10 hari sebelum publikasi annual report dan 10 hari setelah publikasi annual report, untuk annual report periode 1999 2008, yang ditunjukan oleh gambar 1 .

\section{Gambar 1 \\ Rata-rata Harga Saham \\ 10 hari Sebelum dan 10 Hari Setelah Publikasi Annual Report}

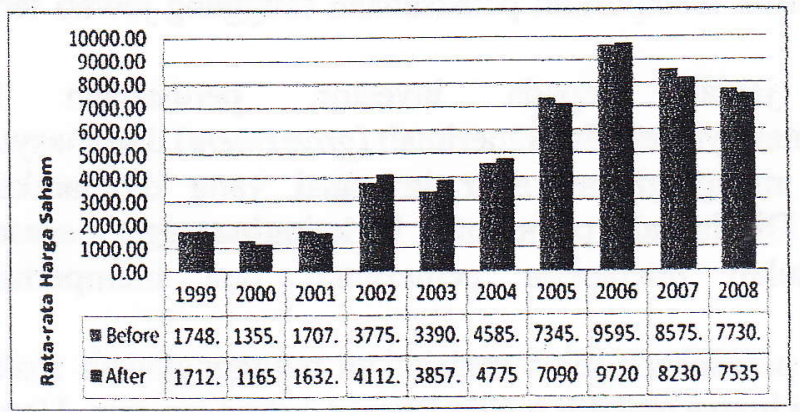

Dari grafik 1.1 di atas dapat dilihat bahwa 5 dari 10 periode publikasi annual report diikuti oleh kenaikan harga saham. Sedangkan untuk tahun 2000, 2001, 2005, 2007 dan 2008 rata-rata harga saham setelah publikasi annual report untuk tahun tersebut ternyata mengalami penurunan. Hal ini menjadi kontradiktif terutama untuk tahun 2007 dan 2008, dimana pada tahun tersebut Telkom mengeluarkan sustainability report yang merupakan bentuk pelaporan khusus untuk CSR sehingga memungkinkan perusahaan untuk melaporkan pertanggungjawaban sosialnya dengan lebih baik lagi.

Banyak faktor yang dapat mempengaruhi pergerakan harga saham perusahaan, antara lain keadaan kondisi keuangan perusahaan kondisi perekonomian dan politik negara, kondisi global, dan khususnya untuk masa sekarang ini pasar juga lebih memperhatikan lagi masalah tanggung jawab sosial yang dilakukan perusahan. Hal ini berkaitan dengan munculnya isu-isu global mengenai pertanggung jawaban sosial perusahaan sehingga para investor menjadikan informasi kinerja perusahaan dalam bidang sosial sebagai bahan pertimbangannya untuk melakukan investasi pada saham perusahaan yang bersangkutan.

Berdasarkan latar belakang di atas penulis tertarik untuk mengambil judul "Pengaruh Tingkat Pengungkapan Corporate Social Responsibility (CSR Disclosure) Terhadap Return Saham (Studi Pada PT. Telekomunikasi Indonesia, Tbk.)".

\section{Rumusan Masalah}

1. Bagaimana tingkat pengungkapan CSR (CSR disclosure) yang dicerminkan oleh tiga standard disclosures yaitu Profile Disclosure, Management Approach Disclosure, Performance Indicators \& Sector Supplement Performance Indicators pada PT Telekomunikasi Indonesia, Tbk.

2. Bagaimana nilai return saham pada priode sekitar tanggal publikasi laporan tahunan perusahaan.

Jurnal Akuntansi Riset, Prodi Akuntansi UPI, Vol. 1, No. 2 
3. Bagaimana pengaruh tingkat pengungkapan CSR terhadap nilai return saham.

\section{Kerangka Pemikiran}

Undang-Undang No. 40/2007 tentang Perseroan Terbatas mewajibkan perseroan yang bidang usahanya di bidang atau terkait dengan bidang sumber daya alam untuk melaksanakan tanggung jawab sosial dan lingkungan. Undang-Undang tersebut juga mewajibkan semua perseroan untuk melaporkan pelaksanaan tanggung jawab tersebut di Laporan Tahunan.

Selain bertanggung jawab kepada investor, perusahaan harus mempertanggungjawabkan kegiatannya kepada pemerintah (goverment) dan masyarakat secara umum. Investor tentu menginginkan agar investasi yang ditanamkan di perusahaan selalu berkembang. Di sisi lain pemerintah berkeinginan agar perusahaan mengikuti peraturan yang telah ditetapkan pemerintah dan memperhatikan tanggungjawab sosialnya.

Untuk melihat apakah perusahaan telah melakukan tanggungjawab sosialnya atau tidak, hal ini tentu tidak bisa hanya melalui media laporan keuangan saja. Untuk itu kini telah muncul suatu bentuk pelaporan baru yang memungkinkan investor, pemerintah, dan masyarakat umum untuk melihat kinerja perusahaan dalam lingkungan sosialnya. Bentuk pelaporan ini dikenal dengan nama Corporate Social Responsibility (CSR). Dalam Ismail Solihin (2009:28) The World Business Council for Sustainable Development (atau saat ini dinamakan Business Action for Sustainable Development) memberikan rumusan CSR sebagai berikut:

CSR adalah komitmen berkelanjutan dari para perilaku bisnis secara etis dan memberi kontribusi bagi pembangunan ekonomi, sementara pada saat yang sama meningkatkan kualitas hidup dari para pekerja dan keluarganya, demikian pula masyarakat lokal dan masyarakat secara luas..

Adanya suatu paradigma baru pelaporan kinerja perusahaan khususnya dalam hubungan perusahaan dengan lingkungan sosialnya telah merubah pandangan pemegang saham dan pengguna laporan keuangan pada saat ini. Mereka tidak hanya memfokuskan pada perolehan laba perusahaan tetapi juga memperhatikan tanggung jawab sosial dan Ingkungan perusahaan. Selain itu, kelangsungan hidup perusahaan pun tidak hanya ditentukan oleh pemegang saham saja, tetapi stakeholder secara keseluruhan.

Epstein dan Freedman dalam Sayekti (2007:8) menemukan bahwa investor individual tertarik terhadap informasi sosial yang diungkapkan dalam laporan tahunan perusahaan. Informasi tersebut mecakup keamanan dan kualitas produk, etika, dan hubungan dengan karyawan dan masyarakat.

Beberapa tahun terakhir ini telah lahir wacana keberlanjutan atau 'sustainaibility' sebagai salah satu tolok ukur keberhasilan yang utama bagi suatu kegiatan usaha. Perusahaan tidak lagi semata-mata mencari laba bagi pemegang saham, melainkan harus mampu memberikan manfaat bagi pemangku kepentingan lainnya termasuk karyawan, pelanggan, mitra usaha, masyarakat, bahkan bangsa dan negara tempat perusahaan itu beroperasi. Karena itu muncul suatu jenis pelaporan baru yang 
dinamakan Sustainability Report dimana di dalam mencakup pelaporan mengenai halhal tersebut, termasuk pengungkapan CSR. Dalam hal pembuatan laporannya, Sustainability Report ini berpedoman pada Global Reporting Initiative (GRI) G3 2006 yang menjadi acuan pelaporan upaya-upaya keberlanjutan bagi sebagain besar perusahaan sedunia. Dimana dalam pelaporannya merupakan informasi tentang kegiatan perusahaan dalam satu periode atau satu tahun, sehingga Sustainability Report ini dapat dikatakan sebagai bagian dari laporan tahunan perusahaan. Dalam GRI ini terdapat tiga standard disclosure untuk mengungkapkan laporan mengenai CSR, yaitu Profile Disclosure, Management Approach Disclosure, dan Performance Indicators \& Sector Supplement Performance Indicators.

Informasi yang diungkapkan perusahaan baik dalam laporan keuangan maupun laporan tahunannya dapat menimbulkan reaksi yang berbeda dari investor. Apabila informasi yang diungkapkan dianggap berita baik (god news) maka hal ini akan menarik minat investor, yang akhirnya akan meningkatkan nilai saham perusahaan khususnya pada waktu sekitar pengumuman laporan kinerja perusahaan tersebut. Sebaliknya, jika informasi yang diungkapkan merupakan kabar yang kurang baik (bad news) atau tidak seperti yang diharapkan investor maka hal ini akan menyebabkan menurunnya nilai saham perusahaan tersebut.

Menurut Jogiyanto (2008:529), pengujian kandungan informasi dimaksudkan untuk melihat reaksi dari suatu pengumuman. Jika pengumuman mengandung informasi (information content), maka diharapkan pasar akan bereaksi pada waktu pengumuman tersebut diterima oleh pasar. Reaksi pasar ditunjukan dengan adanya perubahan harga dari sekuritas bersangkutan. Reaksi ini dapat diukur dengan menggunakan return sebagai nilai perubahan atau dengan menggunakan abnormal return jika menggunakan abnormal return maka dapat dikatakan bahwa suatu pengumuman yang mempunya kandungan informasi akan memberikan abnormal return pada pasar. Sebaliknnya yang tidak mengandung informasi tidak akan memberikan abnormal return kepada pasar..

Abnormal retum selama periode peristiwa (event periode) didefinisikan sebagai selisih antara actual return dengan expected return. Actual return merupakan keuntungan yang dapat diterima atas investasi suatu saham pada periode tertentu. Expected return merupakan keuntungan yang diharapkan oleh investor.

\section{Metode Penelitian}

Penelitian ini merupakan penelitian dengan metodologi studi peristiwa (event study). Dalam penelitian ini event yang diteliti adalah peristiwa pengumuman laporan tahunan. Menurut Jogiyanto (2008:529), studi peristiwa (event study) merupakan studi yang mempelajari reaksi pasar terhadap suatu peristiwa (event) yang informasinya dipublikasikan sebagai suatu pengumuman. Studi peristiwa (event study) dapat digunakan untuk menguji kandungan informasi (information content) dari suatu pengumuman. Tujuannya adalah untuk melihat reaksi pasar dalam menyerap informasi yang dipublikasikan. Ivan Christian (2004:45) mengatakan jika pengumuman mengandung informasi maka diharapkan pasar akan bereaksi pada waktu pengumuman tersebut diterima oleh pasar. Reaksi pasar pada umumnya diukur dengan menggunakan 
abnormal return saham. Perbedaan abnormal return saham yang signifikan pada waktu pengumuman informasi dengan waktu diluar pengumuman informasi mengindikasikan bahwa pasar bereaksi atas publikasi tersebut pasar yang bereaksi.

Sumber data sekunder yang digunakan dalam penelitian ini adalah data laporan tahunan, dalam hal ini annual report dan sustainability report, serta harga saham harian pada sekitar tangal publikasi laporan tahunan pada PT. Telekomunikasi Indonesia selama sepuluh tahun yaitu dari tahun 1999 sampai dengan 2008.

Selanjutnya untuk mengetahui tentang pengaruh. CSR disclosure terhadap variabel terikat, yaitu perubahan Average Abnormal Return ( $\triangle \mathrm{AAR}$ ), penulis melakukan pengolahan data dengan langkah-langkah berikut ini :

1. Mendapatakan data-data yang berkaitan dengan variabel-variabel terkait, antara lain Laporan Tahunan periode 1999-2008, harga saham perusahaan di sekitar tanggal penyerahan laporan keuangan, serta data lain yang berkaitan dengan penelitian ini yang diperoleh langsung dari perusahaan terkait maipun dari pusat referensi, website, jurnal ataupun literatur lainnya.

2. Menghitung abnormal return pada saat tanggal publkasi, 10 hari sebelum dan setelah tanggal publikasi laporan keuangan tahunan lalu melakukan perhitungan perubahan rata-rata abnormal return dari setiap periode ( $\triangle \mathrm{AAR}$ ).

3. Menghitung tingkat CSR disclosure dari perusahaan yang terdiri dari 3 standar disclosure yaitu Profile Disclosure, Management Approach Disclosure, Performance Indicators \& Sector Supplement Performance Indicators.

4. Mengevaluasi data yang sudah ada untuk mengetahui bagaimana pengaruh CSR disclosure yang dicerminkan oleh Profile Disclosure, Management Approach Disclosure, Performance Indicators \& Sector Supplement Performance Indicators terhadap perubahan Average Abnormal Return ( $\triangle \mathrm{AAR}$ ).

Teknik analisis data yang digunakan untuk menganalisis hubungan diantara empat variabel dalam penelitian ini adalah dengan menggunakan model regresi logistik.

Penelitian ini menggunakan SPSS 16.0 (Statistical Package for Social Sciences) for windows untuk mempermudah dan mempercepat perhitungan.

Adapun hipotesis yang akan diuji dalam penelitian ini adalah :

1. Terjadi peningkatan rata-rata abnormal return dari sebelum publikasi laporan tahunan dengan setelah publikasi laporan tahunan.

2. Tingkat pengungkapan CSR yang dicerminkan oleh tiga standard disclosure yaitu Profile Disclosure, Management Approach Disclosure, dan Performance Indicators \& Sector Supplement Performance Indicators, memiliki pengaruh terhadap return saham pada PT Telekomunikasi Indonesia, Tbk. 


\section{Hasil Penelitian}

Pengujian yang akan dilakukan melalui hipotesis 1 ini adalah perbedaan rata-rata abnormal return sebelum dan sesudah pengungkapan. Hasil analisis pengujian hipotesis 2 tersebut dapat dilihat dalam tabel 1 di bawah ini:

Tabel 1

Perbedaan AAR sebelum dan setelah publikasi

Sumber : website Telkom dan BEI (data diolah)

\begin{tabular}{|l|l|l|}
\hline Periode & AAR & Perbedaan \\
\hline $\begin{array}{l}\text { Sebelum } \\
\text { Pengungkapan }\end{array}$ & -0.00068 & 0.00021 \\
\hline $\begin{array}{l}\text { Sesudah } \\
\text { Pengungkapan }\end{array}$ & -0.00047 & \\
\hline
\end{tabular}

Dari tabel 1 di atas terlihat bahwa rata-rata abnormal return selama 10 hari setelah pengungkapan terlihat lebih tinggi dibandingkan sebelum pengungkapan. Dengan demikian hipotesis nol pertama dapat ditolak dan hipotesis alternatifnya dapat diterima, yaitu terjadi peningkatan rata-rata abnormal return setelah publikasi annual report.

Untuk melihat hasil analisis regresi menggunakan model persamaan kedua yang memasukan semua komponen dari variable independen. Berikut ditunjukan oleh tabel 2.

Tabel 2

Variables in the Equation

\begin{tabular}{|c|c|c|c|c|c|c|c|}
\hline & & B & S.E. & Wald & df & Sig. & $\operatorname{Exp}(B)$ \\
\hline \multirow{4}{*}{$\begin{array}{l}\text { Step } \\
1^{\mathrm{a}}\end{array}$} & $\mathrm{X} 1$ & 14.264 & 22.559 & .400 & 1 & .527 & $1.566 \mathrm{E} 6$ \\
\hline & $X 2$ & .091 & 2.915 & .001 & 1 & .975 & 1.095 \\
\hline & $\mathrm{X} 3$ & -3.038 & 19.927 & .023 & 1 & .879 & .04 \\
\hline & Constant & -6.845 & 11.025 & .385 & 1 & .535 & .001 \\
\hline
\end{tabular}

a. Variable(s) entered on step 1: X1, X2, X3.

Dilihat dari tabel diatas bahwa tingkat signifikansi untuk ketiga variabel standar disclosure yaitu Profile Disclosure (X1), Management Approach Disclosure $\left(\mathrm{X}_{2}\right)$, dan Performance Indicators \& Sector Supplement Performance Indicators (X3) lebih besar dari $5 \%$, dimana hasil pada Iteration History yang menunjukan tigkat signifikansi untuk Profile Disclosure (X1) adalah sebesar 0.527, Management Approach Disclosure $\left(\mathrm{X}_{2}\right)$ sebesar 0.975, dan Performance Indicators \& Sector Supplement Performance Indicators (X3) sebesar 0.879. Sehingga dapat dikatakan bahwa Profile Disclosure (X1), Management Approach Disclosure $\left(\mathrm{X}_{2}\right)$, dan Performance Indicators \& Sector 
Supplement Performance Indicators (X3) tidak berpengaruh secara signifikan terhadap $\triangle A R R$.

\section{Pembahasan}

Penelitian ini sesuai dengan penelitian yang dilakukan oleh Widiastuti (2002). Dimana Widiastuti meneliti pengaruh pengungkapan tanggung jawab sosial dengan menggunakan kategori-kategori untuk mengukur CSR seperti kinerja perekonomian, lingkungan, ketenagakerjaan, Sumber Daya Manusia, masyarakat, dan tanggung jawab produk. Widiastuti meneliti pengaruh pengungkapan sosial terhadap earning respons coefficient (ERC), dan menemukan adanya pengaruh positif signifikan dari luas pengungkapan sukarela terhadap ERC, artinya tingkat penungkapan sosial kurang mendapat perhatian investor untuk menentukan aktivitas investasinya dan para investor lebih tertarik kepeda informasi tentang profit atau informasi keuangan dari perusahaan, dapat disimpulkan bahwa dalam penelitiannya pengungkapan pengungkapan informasi sosial tidak berpengaruh secara signifikan terhadap return saham, dan harga return saham lebih dipengaruhi oleh informasi laba.

Kemungkinan penjelasan atas hasil penelitian ini karena investor tidak cukup yakin dengan informasi tanggung jawab sosial yang diungkapkan manajemen sehingga investor tidak menggunakan informasi tersebut sebagai dasar untuk merevisi belief. Kemungkinan penjelasan kedua adalah bahwa para investor di Indonesia masih menganggap informasi mengenai tanggung jawab sosial kurang begitu penting, hal ini dikarenakan sistem pelaporan CSR yang masih tergolong baru dan belum semua perusahaan di Indonesia melakukan pelaporan ini.

Sedangkan dalam penelitian lainnya Yosefa Sayekti (2007) menemukan hasil

yang berbeda, dimana hasil penelitian mengindikasikan bahwa investor mengapresiasi informasi CSR yang diungkapan dalam laporan tahunan perusahaan dengan pengaruh yang signifikan. Pengungkapan informasi dalam laporan tahunan yang dilakukan oleh perusahaan diharapkan dapat mengurangi asimetri informasi dan juga mengurangi agency problems, (Healy dalam Yosefa (2007:7)). Informasi tersebut termasuk CSR, dimana laporan tahunan merupakan salah satu sumber informasi guna mendapatkan gambaran kinerja perusahaan dalam lingkungan sosialnya.

Adapun teori yang mendukung hasil penelitian ini yaitu dimana diungkapan oleh Ismail Solihin (2008), dimana beliau menyatakan bahwa untuk informasi pertanggungjawaban yang diungkapkan oleh perusahaan para investor merespon lamban karena informasi ini merupakan informasi yang bersifat berkelanjutan sehingga akan berpengaruh dimasa depan dalam operasi suatu perusahaan.

Pengungkapan CSR yang dilakukan oleh perusahaan dalam laporan tahunannya juga merupakan salah satu upaya perusahaan dalam menjalankan prinsip Good Corporate Governance. Good corporate governance merupakan konsep yang menekankan pentingnya hak pemegang saham untuk memperoleh informasi dengan benar, akurat, dan tepat waktu serta kewajiban perusahaan untuk mengungkapan (disclosure) secara akurat, tepat waktu, dan transparan mengenai semua informasi 
kinerja perusahaan, kepemilikan, dan stakeholder. Prinsip corporate governance diharapkan dapat meningkatkan kualitas laporan keuangan, yang pada akhirnya meningkatkan kepercayaan pemakai laporan keuangan, termasuk investor. Perusahaan harus mengungkapkan informasi yang relevan mengenai perusahaan termasuk di dalamnya informasi mengenai kinerja perusahaan dalam lingkungan sosialnya dalam bentuk laporan CSR. Pengungkapan informasi CSR dalam laporan tahunan perusahaan akan mengurangi asimetri informasi dan juga mengurangi agency problems. Diharapkan jika perusahaan melakukan pengungkapan informasi CSR dalam laporan tahunannya akan dapat mengurangi masalah tersebut. Hal ini mengindikasikan bahwa investor mengapresiasi informasi CSR yang diungkapkan perusahaan sebagai salah satu dasar pengambilan keputusan investasinya.

Dalam hubungannya CSR sebagai bagian dari konsep Good Corporate Governance, penelitian mengenai Good Corporate Governance di Indonesia telah sering dilakukan. Sulistyanto dan Nugraheni (2002) yang meneliti tentang konsep Good Corporate Governance pada perusahaan yang listed di Bursa Efek Indonesia (BEI). Hasilnya mengindikasikan belum berhasilnya penerapan Good Corporate Governance di Indonesia.

Sementara dalam penelitian lainnya Sri Sulistyanto (2003) yang meneliti tentang reaksi pasar terhadap pengungkapan GCG dalam laporan tahunan perusahaan, menemukan bahwa pasar bereaksi lamban untuk informasi tersebut. Penelitianpenelitian tentang GCG di atas sepaham dengan penelitian ini, yaitu CSR yang merupakan salah satu usaha perusahaan untuk mewujudkan konsep Good Corporate Governance, dimana dapat disimpulkan bahwa belum optimalnya penerapan CSR ataupun Good Corporate Governance di Indonesia sehingga para investor kurang merespon informasi CSR ataupun Good Corporate Governance yang diungkapkan oleh perusahaan dan lebih memperhatikan informasi mengenai kinerja keuangan perusahaan dalam menentukan keputusan investasinya.

Adapun penjelasan lain yang menyebabkan hasil penelitian ini berbeda dengan hasil penelitian sebelumnya yang memperlihatkan pengaruh positif yang signifikan antara tingkat pengungkapan CSR terhadap reaksi pasar adalah dikarenakan pedoman dalam mengukur tingkat pengungkapan CSR berbeda. Penelitian sebelumnya menggunakan pedoman yang berasal dari pendapat para ahli, atau dari teori untuk mengukur tingkat pengungkapan $\mathrm{CSR}$, dimana keragaman dari pengukurannya relatif lebih sederhana dan sempit. Sedangkan dalam penelitian ini digunakan pedoman yang lebih luas yaitu berasal dari GRI yang merupakan pedoman untuk menyusun sustainability report yang merupakan bentuk pelaporan khusus untuk penyususan laporan CSR, dimana GRI ini bertaraf global sehingga dimungkinkan belum bisa digunakan sepenuhnya untuk penelitian dalam rangka mengukur tingkat pengungkapan CSR bagi perusahaan di Indonesia.

Simpulan

Dari penelitian mengenai pengaruh CSR disclosure yang terdiri dari Profile Disclosure, Management Approach Disclosure, dan Performance Indicators \& Sector Jurnal Akuntansi Riset, Prodi Akuntansi UPI, Vol. 1, No. 2 
Supplement Performance Indicators terhadap perubahan average abnormal return pada Perusahaan Telkom tahun 1999-2008 di Bursa Efek Indonesia, maka dapat diambil simpulan sebagai berikut :

1. Tingkat pengungkapan CSR yang dicerminkan oleh tiga standard disclosures yaitu Profile Disclosure, Management Approach Disclosure, dan Performance Indicators \& Sector Supplement Performance Indicators pada perusahaan PT. Telekomunikasi Indonesia untuk periode 1999-2008 relatif mengalami peningkatan terutama untuk tiga tahun terakhir, hal ini berhubungan dengan dilakukannya publikasi Sustainability Report oleh perusahaan untuk tiga tahun terakhir tersebut sehingga mengharuskan perusahaan untuk melaporkan kinerja sosial perusahaan dengan lebih baik lagi.

2. Tingkat return saham yang terjadi setelah publikasi annual report relatif mengalami peningkatan dari sebelum publikasi annual report, dimana ditunjukan dengan mayoritas nilai selisih antara average abnormal return setelah publikasi dan sebelum publikasi menghasilkan nilai yang positif. Kemungkinan peningkatan average abnormal return ini salah satunya disebabkan oleh publikasi annual report tersebut, ini mengindikasikan bahwa publikasi annual report mendapatkan reaksi yang positif dari pasar.

3. Dari hasil penelitian menunjukkan bahwa ketiga variabel bebas yang mencerminkan CSR disclosure yaitu Profile Disclosure, Management Approach Disclosure, dan Performance Indicators \& Sector Supplement Performance Indicators tidak berpengaruh secara signifikan terhadap perubahan Average Abnormal Return pada sekitar tanggal publikasi annual report.

Saran berikut:

Adapun saran yang dapat direkomendasikan penulis dalam penelitian ini sebagai

1. Bagi Investor. Investor hendaknya memperhatikan pengungkapan sosial yang dilakukan olleh perusahaan, dan menjadikan pengungkapan sosial sebagai salah satu pertimbangan dalam pengambilan keputusan ketika akan melakukan investasi. Sehingga nantinya perusahaan merasa mempunyai rasa tanggung jawab sosial terhadap lingkungannya.

2. Bagi perusahaan. Khususnya untuk Telkom dan umumnya untuk seluruh emiten diharapakan menyajikan pengungkapan sosial dalam laporan tahunannya dengan lebih baik lagi, yaitu sesuai dengan pedoman yang telah ditetapkan GRI, sehingga nantinya dapat dijadikan sebagai bahan pertimbangan bagi investor untuk melakukan investasi.

3. Bagi peneliti selanjutnya

a. Bagi peneliti selanjutnya diharapkan dapat menambah jumlah perusahaan emiten sehingga nantinya dapat diketahui dengan lebih mendalam bagaimana sebenarnya pengaruh pengungkapan CSR terhadap return saham.

b.Penelitian ini hanya menggunakan CSR disclosure saja sebagai variable bebas, untuk selanjutnya menarik untuk diteliti bagaimana pengaruh faktor lainnya 
seperti kinerja keuangan perusahaan,,keadaan perekonomian dan politik, sehingga dapat dijadikan perbandingan juga faktor mana saja yang paling berpengaruh dalam mempengaruhi return saham.

\section{Daftar Pustaka}

Ahmed Riahi, dan Balkaoui. 2006. Teori Akuntansi Edisi 5. Jakarta : Salemba Empat.

Dedi Junaedi. 2005, "Dampak Tingkat Pengungkapan Informasi Perusahaan terhadap

Volume Perdagangan dan Return Saham: Penelitian Empiris terhadap

Perusahaan-Perusahaan yang Tercatat di Bursa Efek Jakarta", Jurnal Akuntansi dan Keuangan Indonesia, Vol. 2, No. 2, pp. 1-28.

Dian Purwita Sari. 2007. Pengaruh Pengukuran Kinerja Perusahaan Berdasarkan EVA

(Economic Value Added) dan ROA (Return On Assets) Terhadap Reaksi Pasar

Yang Dicerminkan Oleh Abnormal Return. Skripsi. FE UNPAD.

Harjanti Widiastuti. 2002. "Pengaruh Luas Ungkapan Sukarela dalam Laporan

Tahunan terhadap Earning Response Coefficient (ERC)", Simposium Nasional Akuntansi V, Semarang 5-6 2003.

Hendrik Budi Untung. 2008. Corporate Social Responsibility. Jakarta : Sinar Grafika.

Ikatan Akuntan Indonesia (IAI). 2007. Pedoman Standar Akuntansi Keuangan 2007.

Imam Ghozali. 2007. Aplikasi Analisis Multivariate dengan program SPSS. Semarang :

Badan Penerbir Undip.

Ismail Solihin. 2009. Corporate Social Responsibility From Charity to Sustainnability.

Jakarta : Salemba Empat.

Ivan Christian. 2004. Reaksi Investor Atas Pengumuman Dividen Terhadap Abnormal

Return Dan Volume Perdagangan Saham. Tesis. Magister Manajemen Widyatama.

Jogiyanto Hartono. 2008. Teori Portofolio dan Analisis Investasi. Edisi Kelima. Yogyakarta : BPFE - Yogyakarta.

Mudrajad Kuncoro. 2007. Metode Kuantitatif : Teori dan Aplikasi Untuk Bisnis dan Ekonomi. Yogyakarta : UPP STIM YKPN.

Muhammad Muslim Utomo. 2000. Praktek Pengungkapan Sosial Pada Laporan Tahunan Perusahaan di Indonesia (Studi Perbandingan antara Perusahaanperusahaan High Profile dan Low Profile). Simposium Nasional Akuntansi III.

Nana Sudjana dan Ibrahim. 2004. Penelitian dan Penilaian Pendidikan. Bandung: Sinar Baru Algensindo..

Purbayu Budi Santosa dan Ashari. 2005. Analisis Statistik dengan Microsoft Exel dan SPSS. Yogyakarta : Andi.

Reni Retno Anggraini Fr. (2006), "Pengungkapan Informasi Sosial dan Faktor-Faktor yang Mempengaruhi Pengungkapan Informasi Sosial dalam Laporan Keuangan Tahunan (Studi Empiris pada Perusahaan-Perusahaan yang terdaftar di Bursa Efek Jakarta)", Simposium Nasional Akuntansi 9.

Rina Tresnawati. 2008. Pengaruh Sebelum Dan Setelah Penerapan Corporate Social Responsibility Terhadap Profitabilitas Perusahaan. Skripsi. Fakultas Ekonomi Universitas Widyatama. 
Sastradipoera Komaruddin. 1997. Metode Penulisan Skripsi dan Tesis. Bandung : Kappa Sigma.

Sudjana. 1997. Statistika Untuk Ekonomi dan Niaga II. Bandung : Tarsito.

Sudjana. 2000. Statistika Untuk Ekonomi dan Niaga I. Bandung : Tarsito.

Sugiyono. 2007. Statistik Untuk Penelitian. Bandung: Alfabeta.

Sugiyono. 2008. Metode Penelitian Bisnis. Bandung : Alfabeta

Suharsimi Arikunto. 2006. Proses Penelitian Suatu Pendekatan Praktek. Jakarta : Rineka Cipta

Suharsimi Arikunto. 2002. Prosedur Penelitian Suatu Pendekatan Praktek. Edisi Revisi $V$. Jakarta : Rineka Cipta

Sunariyah. 2006. Pengantar Pengetahuan Pasar Modal. Edisi Kelima. Yogyakatra : UPP STIM YKPN.

Sri Sulistyanto. 2003. Good Corporate Governance : Bisakah Meningkatkan Kepercayaan Masyarakat. Jurnal Ekonomi dan Bisnis, Vol.4/No.1/Januari 2003, Fakultas Ekonomi Universitas Islam Sultan Agung Semarang.

Tim Dosen Akuntansi UPI. 2008. Pedoman Penulisan Skripsi. Bandung : Bagian Penerbitan Program Studi Akuntansi UPI.

Tienike Oni Hayati. 2007. "Pengaruh Luas Pengungkapan Sosial Dalam Laporan Tahunan Perusahaan Terhadap Volume Perdagangan Dan Return Saham". Skripsi. Fakultas Ekonomi Universitas Brawijaya.

Yosefa Sayekti dan Ludovicus Sensi Wondabio.2007. Pengaruh CSR Disclosure Terhadap Earning Response Coefficient. Simposium Nasional Akuntansi X. 